\title{
Epipsammic diatoms in streams influenced by urban pollution, São Carlos, SP, Brazil
}

\author{
Bere, T.* and Tundisi, JG. \\ Instituto Internacional de Ecologia - IEE, Rua Bento Carlos, 750, Centro, São Carlos, SP, Brasil \\ *e-mail: taubere@yahoo.com
}

Received May 6, 2009 - Accepted August 31, 2009 - Distributed November 30, 2010

(With 5 figures)

\begin{abstract}
Epipsammic diatoms have important implications for ecosystem processes in lotic environments. Most of the studies on benthic diatoms concentrate on epilithic diatoms and very little is known about epipsammic diatoms. The objective of this study was to assess epipsammic diatom communities in streams in relation to environmental conditions. Epipsammic diatoms and water quality sampling was done at 7 sites during summer base flow period (2008). Forward stepwise multiple regression and canonical correspondence analysis (CCA) were used to determine environmental gradients along which species vary with physical and chemical variables. A total of 112 diatom species distributed among 44 genera were recorded. Altitude and the process of eutrophication played a significant role in structuring diatom communities in the study region.
\end{abstract}

Keywords: diatom communities, pollution, environmental gradients, biological monitoring.

\section{Epipsammic diatomáceas em riachos influenciada pela poluição urbana, São Carlos-SP, Brasil}

\begin{abstract}
Resumo
Diatomáceas epipsâmicas têm implicações importantes para os processos em ecossistemas em ambientes lóticos. A maioria dos estudos sobre diatomáceas bentônicas concentra-se em diatomáceas epilíticas e muito pouco se sabe sobre diatomáceas epipsâmicas. O objetivo deste estudo foi avaliar comunidades de diatomáceas epipsâmicas nos córregos em relação às condições ambientais. Amostragens de diatomáceas epipsâmicas e de água para determinação da qualidade foram feitas em sete locais durante o verão do ano de 2008. As análises de regressão múltipla passo a passo e análise de correspondência canônica (CCA) foram usadas para determinar quais espécies ao longo dos gradientes ambientais variam de acordo com as variáveis físicas e químicas da água. Um total de 112 espécies de diatomáceas distribuídas entre 44 gêneros foi registrado. A altitude e o processo de eutrofização exerceram um papel significativo na estruturação das comunidades de diatomáceas na região de estudo.
\end{abstract}

Palavras-chave: comunidades de diatomáceas, poluição, gradientes ambientais, monitoramento biológico.

\section{Introduction}

Lotic ecosystems present unique patterns of distribution of biological diversity among taxonomic groups and among regions (Allan and Flecker, 2003; Tundisi and Matsumura-Tundisi, 2008). These patterns are responsive to the nature of physical and chemical characteristics of lotic environments. The integrity of biota inhabiting lotic ecosystems thus provides a direct, holistic and integrated measure of the integrity of the system as a whole (Karr, 1991).

A fundamental part of biota of lotic ecosystems is the periphyton community. The main part of periphyton consists of diatoms which are various microscopic one-celled or colonial members of the algal division or phylum Bacillariophyta. Diatoms are the most species rich group of algae with tens of thousands of species (Mann, 1999; Moura et al., 2007). Round (1991) states that there are currently over 260 genera of living diatoms with over 100,000 species.

Diatoms are cosmopolitan, with others being endemic to specific regions (Kelly, 1998; Potapova and Charles, 2003). Their community structures in streams are controlled by multiple factors prevailing at different temporal and spatial scales (Biggs, 1995; Stevenson, 1997; Pan et al., 1996). These factors include water chemistry (particularly $\mathrm{pH}$, ionic strength and nutrient concentrations), substrate, current velocity, light (degree of shading) grazing and temperature (which also correlate strongly with latitude and altitude) (Patrick and Reimer, 1966; Round, 1991; Pan et al., 1996; Potapova and Charles, 2002; Necchi-Júnior et al., 2003, Moura et al., 2007). 
Most of these factors depend strongly on climate, geology, topography, land-use and other landscape characteristics, and therefore diatom communities are similar within ecological regions defined by these characteristics (Pan et al., 1996). Short-term differences in community composition are also driven by immigration of cells, differences in growth rate between populations and loss processes such as death, emigration and sloughing.

Most of the studies carried out on benthic diatoms tend to concentrate on epilithic diatoms (growing on stones) and very little is known about epipsammic diatoms (growing on sand) despite their ecological importance in the structure and functioning of lotic systems (Krecji and Lowe, 1986). The patterns of epipsammic diatom taxa distributions and their underlying causes have, therefore, largely been unexplored. This study was designed to assess epipsammic diatom communities in streams in relation to environmental conditions.

\section{Material and Methods}

\subsection{Study area}

The area under study (Figure 1 ) is bound by latitudes $22^{\circ} 00^{\prime}$ and $22^{\circ} 30^{\prime} \mathrm{S}$, and longitude $47^{\circ} 30^{\prime}$ and $48^{\circ} 00^{\prime} \mathrm{E}$. Headwaters of the study streams (Monjolinho, Gregório and Água Quente) fall within mainly agricultural area. Apart from agricultural practices in the headwaters, the study area is predominantly urban. The city of São Carlos covers a total area of $1143.9 \mathrm{~km}^{2}$. The area is characterised by rugged topography and an average annual temperature of around $19.5^{\circ} \mathrm{C}$, with a mean monthly maximum of around $21.9{ }^{\circ} \mathrm{C}$ recorded in January and February and the mean monthly minimum of around $15.9{ }^{\circ} \mathrm{C}$ recorded in July.

In 2008, the population of São Carlos was estimated at 218,080 inhabitants by the Instituto Brasileiro de Geografia e Estatística (IBGE). The expansion of the city at the moment does not meet the technical standards that should go with it in terms of streets, sewage treatment and collection of garbage, urban drainage, water supply, road system and recreational area. The council also does not have an adequate system of sorting and disposal of waste. Streams in the study area, therefore, receive untreated or semi-treated effluent from various domestic and industrial sources as well as other diffuse sources as they pass through the city of São Carlos. The city has also expanded without taking into account environmental, geological and topographical factors leading to deforestation, erosion and siltation. This disorderly growth of São Carlos promoted: a) deterioration of stream health; b) erosion of soil; c) flooding; d) loss of the remaining primary vegetation; and e) eutrophication and contamination of surface and underground aquifers.

A total of 7 sites were established in three stream systems; 2 sites in the headwaters, 2 sites in the urban area,
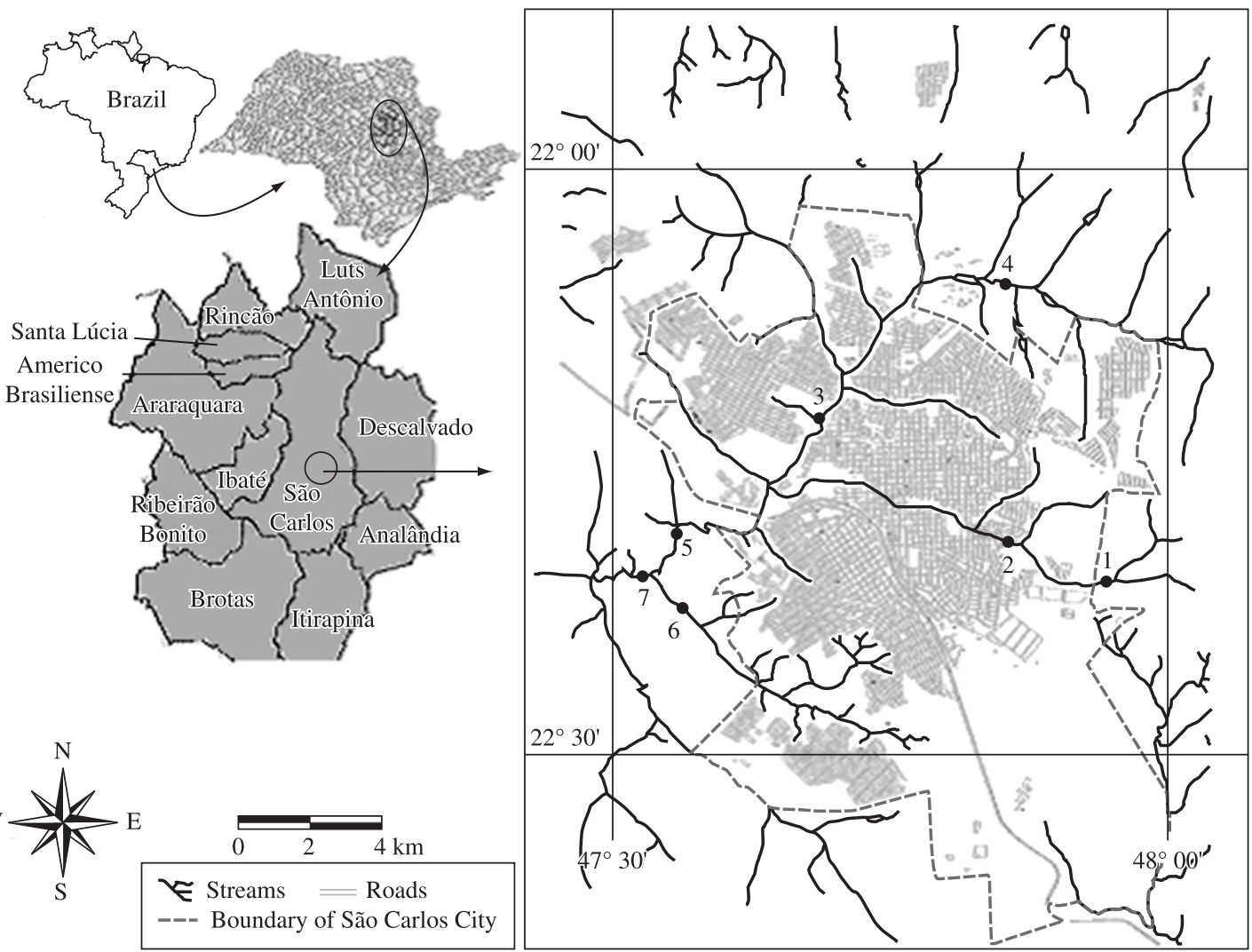

Figure 1. The location of the study area and sampling sites. 
and 3 sites downstream after the urban area. The rational for choosing the sampling sites was to obtain a pollution gradient of all the stream systems from relatively unpolluted headwaters to highly polluted downstream sites.

\subsection{Data collection}

Diatom and water quality sampling was done during the summer season when flow was stable (September to October 2008). The dry season was selected to avoid variable effects of rainy season like great variations in water level and velocity, floods and inundations, which affect diatom development, especially growth rate and relative abundance of different species (Round, 1991; Biggs, 1990, 1995; Patrick and Hendrickson, 1993; Duong et al., 2006). At each site, dissolved oxygen (DO), electrical conductivity, temperature, $\mathrm{pH}$, concentration of total dissolved solids (TDS) and turbidity were measured using a Horiba U-23 and W-23XD Water Quality Meter (Horiba Ltd, Japan).

The depth and current velocity were maintained relatively uniform among all the sites $(10-30 \mathrm{~cm}$ and $1.5-2.0 \mathrm{~m} / \mathrm{s}$ respectively). The percentage riparian vegetation cover was estimated at each site. Altitude was determined at each site using a GPS (Northport Systems, Inc. Toronto, Canada). Light intensity was measured using an LI-193 Spherical Quantum Sensor (LI-COR Worldwide, Brazil).

Water samples for total nitrogen (TN) and total phosphorus (TP) analysis were also collected at each site into acid-cleaned polyethylene bottles Valderrama (1981). No preservations were added to the samples before analysis but they were refrigerated within 12 hours of collection.

Epipsammic diatoms were sampled by pressing a petri dish lid $\left(\right.$ area $\left.=17 \mathrm{~cm}^{2}\right)$ into the top layer of sand to a depth of 5-7 $\mathrm{mm}$ followed by sliding a spatula blade under the petri dish to isolate the contents in the dish which were then gently brought to the surfaces. The contents were then empted into a labelled container. Samples from 6 locations in each sampling reach of about 20-30 m were pooled into a single sample; the total area sampled was $102 \mathrm{~cm}^{2}$.

\subsection{Laboratory analysis}

The concentration of total nitrogen in the water samples was determined following the method by Golterman et al. (1978). The concentration of total phosphorus was also determined following the method by Valderrama (1981).

Sub-samples of the diatom suspensions were cleaned of organic material using wet combustion with concentrated sulphuric acid and mounted in Naphrax (Northern Biological supplies Ltd. UK. RI = 1.74) following Biggs and Kilroy (2000). Three replicate slides were prepared for each sample. A total of 250-600 frustules per sample (depending on the abundance of diatoms) were identified and counted using the phase contrast light microscope $(1000 \times)$. The diatoms were identified to species level based on studies by Mizuno (1964), Patrick and Reimer (1966), Bourrelly (1981), Lobo et al. (1996), John (2000) Biggs and Kilroy (2000), Oliveira et al. (2001), Lobo et al. (2002), Lobo et al. (2004), Bicudo and Menezes (2006),
Salomoni et al. (2006), Delgado et al. (2007), Moura et al. (2007), Soares et al. (2007) and Zalocar de Damitrovic et al. (2007) and the following website: http://diatom. acnatsci.org.

\subsection{Data analysis}

Diatom species counts from each site were expressed as relative abundances. Species richness (S), Shannon's diversity $\left(\mathrm{H}^{\prime}\right)$ and equitability indices (E) calculated according to Shannon and Weaver (1946) were used as measures of community structure. A nonparametric test, Mann-Whitney $U$-test, was used to compare means of S, H' and E from highly polluted sites (5, 6 and 7) and relatively less polluted sites (1, 2, 3 and 4).

Cluster analysis with single linkage and Euclidian distance was performed with physical and chemical variables, species richness, diversity and evenness standardised data matrix to show the main differences and similarities in physical and chemical variables and community structure among the 7 sites sampled. The Mann-Whitney $U$-test was used to compare means of measuring environmental variables from the polluted and unpolluted area.

The original diatom data set consisted of 112 diatom species. Input for numerical analysis included the diatom taxa that were present in a minimum of two samples and had a relative abundance of $\geq 5 \%$ in at least one sample, following Lobo et al. (1996), Potapova and Charles (2003, 2005) and Doung et al. (2007). Of the 112 diatom taxa recorded in the 7 sites, a total of 13 met these criteria. The data set for subsequent analyses consisted of 7 samples $\times 13$ diatom taxa $\times 13$ physical and chemical variables. The distribution of turbidity was positively skewed, and thereforewas $\ln (x+1)$ transformed (Zar, 1984).

The significance of the measured environmental variables in explaining species composition data was carried out in two ways. Firstly, groups of significantly correlated environmental variables were identified from a Pearson's correlation matrix ( $\mathrm{p} \leq 0.05)$. A forward stepwise multiple regression analysis method was then used to determine the environmental variable in each group that explained the greatest amount of variance in the diatom species diversity data. This environmental variable was then used in subsequent analyses as a representative of that particular group of correlated variables, eliminating other variables, thus taking care of multi-colinearity in the data. Variables that did not contribute to the regression where also eliminated. Of the 13 measured environmental variables, 5 variables (altitude, canopy cover, TP, turbidity and $\mathrm{pH}$ ) were selected. Each of these variables therefore represented a group of significantly correlated values. A final forward stepwise multiple regression analysis was then performed using the remaining variables as independent variables and Shannon's species diversity as dependent variable.

Secondly, patterns of floristic variation in data explained by the measured environmental variables, selected according to the criteria above, were detected by canonical correspondence analysis (CCA). An environmental data matrix was constructed 
using five of the 13 environmental variables (altitude, canopy, TP, turbidity and $\mathrm{pH}$ ) that were identified based on the above criteria. This environmental data and species data matrix of the 13 most frequently occurring diatom species were used to perform CCA. Monte Carlo permutation tests ( 99 unrestricted permutations, $\mathrm{p} \leq 0.05$ ) were used to test the significance of the axis and hence determine if the selected environmental variables could explain nearly as much variation in the diatom data as all the 13 environmental variables combined (Ter Braak, 1988).

All statistical analysis, Cluster analysis, Mann-Whitney $U$-test, Multiple regressions and Pearson's Correlation Analysis were performed using the STATISTICA software package (Release 7, Stat Soft. Inc., USA). CCA was performed using PAlaeontological STatistics (PAST) software version 1.90 (Hammer et al., 2009).

\section{Results}

The values of physical and chemical variables measured in the study area during the study period are shown in Table 1. The water quality generally tended to deteriorate downstream as the streams pass through the urban area due to discharge of treated and untreated effluent as well as other diffuse sources of pollution from the city. The $\mathrm{pH}$ presented values slightly inferior to neutral $\mathrm{pH}$. Temperature, conductivity, turbidity, $\mathrm{TN}$ and TP tended to increase downstream while dissolve oxygen and altitude tended to decrease downstream. TN and TP differed significantly between relatively less polluted sites (1, 2, 3 and 4) and highly polluted sites (5, 6 and 7) being low in the former group compared to the later group (Mann-Whitney $U$-test unilateral, $\mathrm{p} \leq 0.05$ ).

A total of 112 diatom species belonging to 44 genera that are distributed among the families Achnanthidiaceae, Achnanthaceae, Bacillariaceae, Eunotiaceae, Cymbellaceae, Gomphonemataceae, Fragilariaceae, Melosiraceae, Naviculaceae, Rhoicospheniaceae, Rhopalodiaceae and Surirellaceae were recorded in all the diatom samples collected. Of the 112 species observed, 13 species (Figure 2 and 3) were considered to be the most frequently occurring in the study area (5\% occurrence and present in at least 2 samples).

There was no significant difference in species richness, diversity and equitability (Mann-Whitney $U$-test, $\mathrm{p} \leq 0.05$ ) among sampling sites, though they showed a general tendency

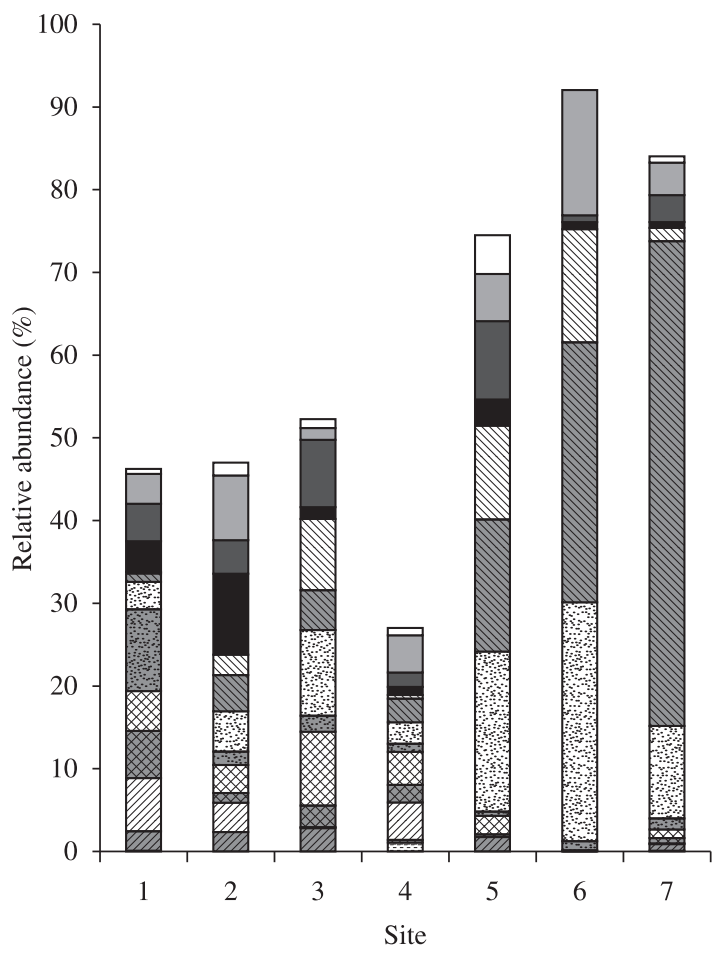

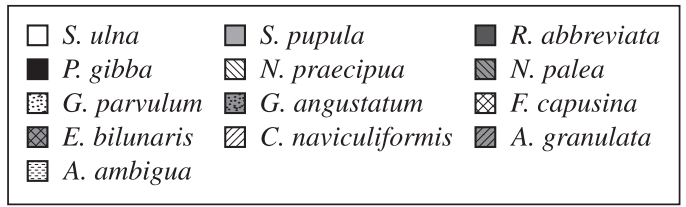

Figure 2. The relative abundances of the most frequently occurring diatom.

Table 1. The values of physical and chemical variables measured on all the sites.

\begin{tabular}{|c|c|c|c|c|c|c|c|}
\hline Site & 1 & 2 & 3 & 4 & 5 & 6 & 7 \\
\hline Temperature $\left({ }^{\circ} \mathrm{C}\right)$ & 20.6 & 21.1 & 21.2 & 24.0 & 24.8 & 23.0 & 21.3 \\
\hline Conductivity $\left(\mu \mathrm{S} . \mathrm{cm}^{-1}\right)$ & 53.0 & 89.0 & 103.0 & 28.0 & 715.0 & 322.0 & 283.0 \\
\hline DO (mg.L $\left.\mathrm{L}^{-1}\right)$ & 7.1 & 4.9 & 4.5 & 3.0 & 3.4 & 3.2 & 1.8 \\
\hline $\mathrm{pH}$ & 6.2 & 7.0 & 7.4 & 6.7 & 7.3 & 7.6 & 7.5 \\
\hline Turbidity (NTU) & 0.0 & 0.0 & 0.0 & 0.0 & 0.1 & 0.1 & 0.1 \\
\hline TDS (g.L $\left.\mathrm{L}^{-1}\right)$ & 22.6 & 57.4 & 66.5 & 18.1 & 458.0 & 206.0 & 181.7 \\
\hline $\mathrm{TN}\left(\mathrm{mg} \cdot \mathrm{L}^{-1}\right)$ & 0.24 & 1.29 & 1.41 & 1.72 & 38.32 & 14.87 & 10.17 \\
\hline $\mathrm{TP}\left(\mathrm{mg} \cdot \mathrm{L}^{-1}\right)$ & 0.01 & 0.16 & 0.06 & 0.03 & 2.97 & 1.11 & 0.75 \\
\hline Altitude (m) & 831.0 & 794.0 & 745.0 & 774.0 & 724.0 & 630.0 & 627.0 \\
\hline Canopy cover $(\%)$ & 60.0 & 50.0 & 4.0 & 20.0 & 20.0 & 50.0 & 5.0 \\
\hline Light intensity $\left(\mu \mathrm{mol} / \mathrm{s} \mathrm{m}^{-2}\right)$ & 431.0 & 1500.0 & 2110.0 & 1645.0 & 1780.0 & 1996.0 & 2212.0 \\
\hline Width (m) & 2.0 & 3.3 & 5.0 & 3.5 & 20.0 & 5.0 & 15.0 \\
\hline Depth (m) & 0.6 & 0.6 & 0.3 & 0.4 & 0.9 & 0.4 & 0.5 \\
\hline
\end{tabular}



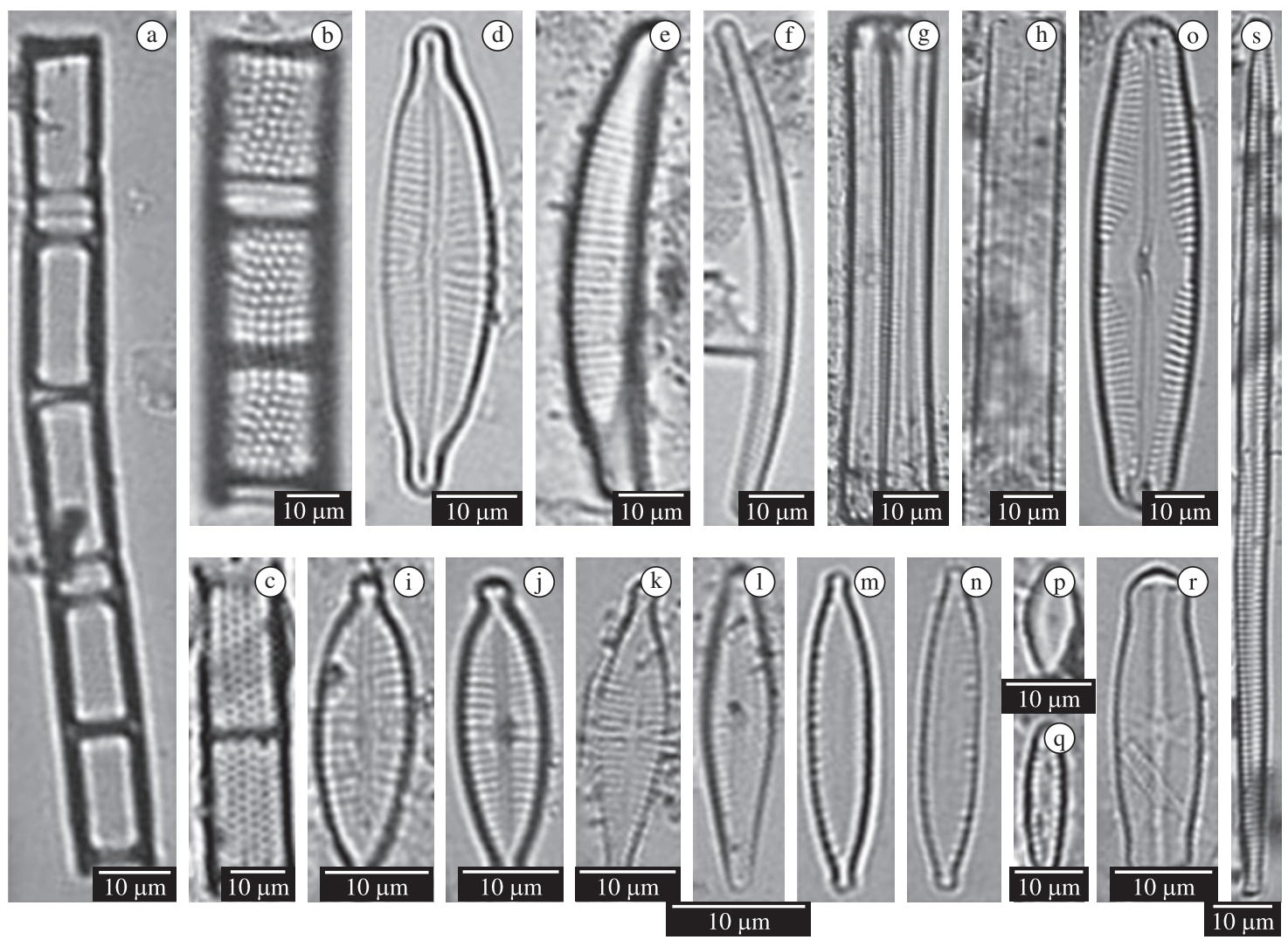

Figure 3. The most frequently occurring diatom species. a) Aulacoseira ambigua (Grunow) Simonsen, b) and c) Aulacoseira granulata (Ehrenberg) Simonsen, d) Cymbopleura naviculiformis (Auerswald) Krammer, e) and f) Eunotia bilunaris (Ehrenberg) Mills, g) and h) Fragilaria capucina Desmaziéres, i), j) and k) - Gomphonema parvulum (Kützing) Cleve, 1) Gomphonema angustatum (Kützing) Rabenhorst, m) and n) Nitzschia palea (Kützing) Smith, o) Pinnularia gibba (Ehrenberg) Grunow, p) Nupela praecipua (Reichardt) Reichardt, q) Rhoicosphenia abbreviata (Agardh) Lange-Bertalot, r) Sellaphora pupula (Kützing) Mereschkowsky, s) Synedra ulna (Nitzsch) Ehrenberg, 19 -20 -. Scale bars correspond to $10 \mu \mathrm{m}$.

of being higher in relatively less polluted (1,2,3 and 4), compared to highly polluted, sites (5, 6 and 7$)$.

From cluster analysis results, two major distinct groups of sites were separated at a linkage distance of about 100 (Figure 4). The separation can be attributed to pollution; one group consisted of relatively less polluted sites (site 1,2, 3 and 4), while the other group consisted of sites from the highly polluted area. Site 7 , which was the furthest downstream, tended to be more similar to the upstream relatively less polluted sites compared to the other sites.

The final forward stepwise multiple regression analysis performed using altitude, canopy cover, TP, turbidity and $\mathrm{pH}$ as independent variables and Shannon's species diversity as dependent variable significantly explained the data (as shown in Table 2). Of the 5 variables, only 3 (altitude, canopy cover and turbidity) were retained after forward stepwise multiple regression. Altitude was found to be significantly contributing to the model ( $b e t a=1.17$, $\mathrm{R}^{2}=0.71, \mathrm{p} \leq 0.05$ ), as shown in Table 3, in agreement with CCA results. This has been noted by several authors (e.g. Biggs and Kilroy, 2000; Oliveira et al., 2001; Potapova
Table 2. The species richness, Shannon's diversity and equitability indices for the different microhabitats sampled during the study period.

\begin{tabular}{cccccccc}
\hline Site & $\mathbf{1}$ & $\mathbf{2}$ & $\mathbf{3}$ & $\mathbf{4}$ & $\mathbf{5}$ & $\mathbf{6}$ & $\mathbf{7}$ \\
\hline $\begin{array}{c}\text { Species } \\
\text { richness }(S)\end{array}$ & 47.0 & 33.0 & 49.0 & 58.0 & 31.0 & 14.0 & 26.0 \\
$\begin{array}{c}\text { Species } \\
\text { diversity }\left(H^{\prime}\right)\end{array}$ & 3.11 & 2.91 & 3.01 & 3.78 & 2.31 & 1.33 & 2.47 \\
$\begin{array}{c}\text { Species } \\
\text { equitability }(E)\end{array}$ & 0.81 & 0.83 & 0.77 & 0.93 & 0.67 & 0.50 & 0.76 \\
\hline
\end{tabular}

and Charles, 2002). The contribution of other variables was not significant.

The results of CCA are presented in Figure 5. The CCA explained a large proportion of the diatom species variance; CCA axis 1, eigenvalue $=0.40$ and axis 2 , eigenvalue $=0.24$. Monte Carlo unrestricted permutation test indicated that axis 1 (99 permutations) and axis 2 (99 permutations of axis 2 with axis 1 as a covariable) were statistically significant $(\mathrm{p} \leq 0.05)$. CCA axis 1 and 2 roughly separated relatively less polluted sites (1, 2, 3 and 4$)$ from highly 
Table 3. Summary of stepwise multiple regression of Shannon-Weiner's diversity indices with physical and chemical variables. Significant betas are highlighted.

\begin{tabular}{lrccc}
\hline \multicolumn{1}{c}{$\begin{array}{c}\text { Step } \\
\text { +in/-out }\end{array}$} & Beta & $\boldsymbol{R}^{\mathbf{2}}$ & p-level & $\begin{array}{c}\text { Variables } \\
\text { included }\end{array}$ \\
\hline Altitude & $\mathbf{1 . 1 7}$ & $\mathbf{0 . 7 1}$ & $\mathbf{0 . 0 4}$ & $\mathbf{1}$ \\
Canopy cover (\%) & -0.40 & 0.47 & 0.09 & 2 \\
pH (g.L $\left.{ }^{-1}\right)$ & -11.49 & 0.99 & 0.13 & 3 \\
\hline
\end{tabular}

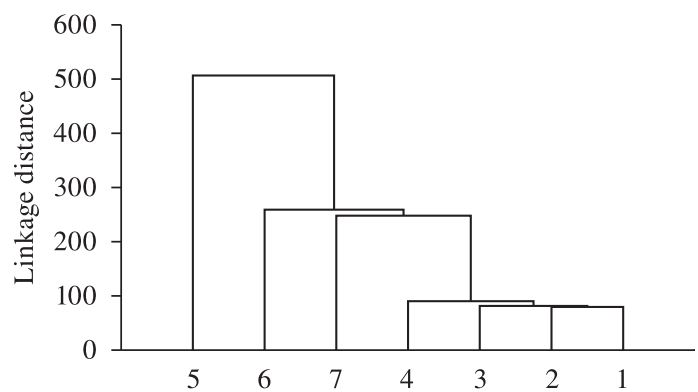

Figure 4. A single linkage, Euclidean distance classification of sites using physical and chemical variables and species diversity, richness and equitability.

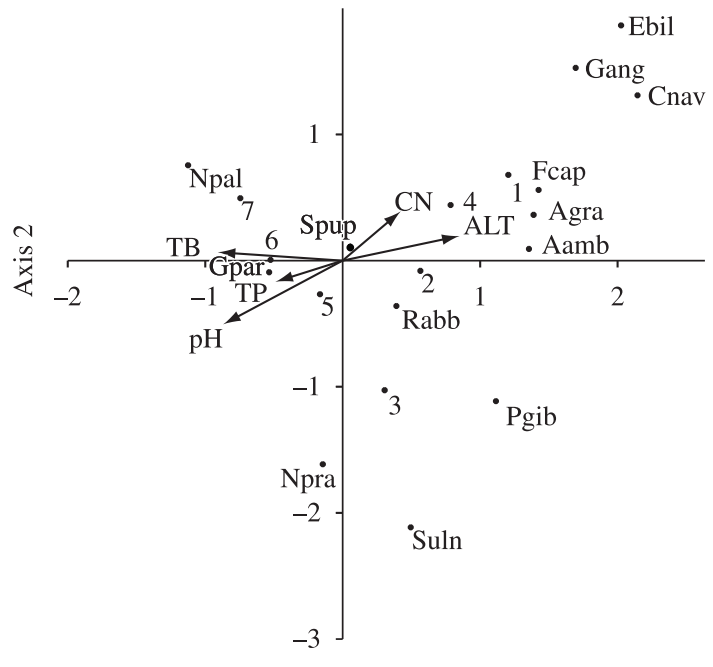

Axis 1

Figure 5. Ordination diagram based on canonical correspondence analysis (CCA) of most frequently occurring diatom species composition in 7 sampling sites with respect to five environmental variables (ALT, altitude; $\mathrm{CN}$, canopy cover; TB, turbidity; TP, total phosphorus and $\mathrm{pH}$ ). Aamb, A. ambigua; Agra, A. granulate; Cnav, C. naviculiformis; Gpar, G. parvulum; Npal, N. palea; Npra, N. praecipua; Rabb, R. abbreviata; Spup, S. pupula; Ebil, E. bilunaris; Fcap, F. capucina; Gang, G. angustatum; Pgib, P. gibba; Suln, S. ulna.

polluted sites (5, 6 and 7). The former group of sites was associated with high altitude, high canopy cover (which was highly negatively correlated to temperature, light intensity and mean stream width), low turbidity, slightly alkaline $\mathrm{pH}$ and low TP (which was highly positively correlated with TDS, TN, conductivity and depth) while the latter group of sites was associated with low altitude, low canopy cover, high turbidity, slightly acidic $\mathrm{pH}$ and high TP.

The upstream, relatively less polluted, sites (1 and 4) were characterised by such species as Aulacoseira ambigua (Grunow) Simonsen, Aulacoseira granulata (Ehrenberg) Simonsen, Cymbopleura naviculiformis (Auerswald) Krammer, Eunotia bilunaris (Ehrenberg) Mills, Fragilaria capucina Desmaziéres, and Gomphonema angustatum (Kützing) Rabenhorst. These species were highly positively associated with CCA axis 1.

On the other hand, downstream, highly polluted sites (5, 6 and 7) were characterised by Gomphonema parvulum (Kützing) Cleve and Nitzschia palea (Kützing) Smith (negatively related to CCA axis 1) which have been reported to be highly pollution tolerant (Round, 1991; Biggs and Kilroy, 2000; Potapova and Charles, 2003; Duong et al., 2006) and Sellaphora pupula (Kützing) Mereschkowsky. Sites 2 and 3 were dominated by Pinnularia gibba (Ehrenberg) Grunow, Nupela praecipua (Reichardt) Reichardt, Rhoicosphenia abbreviata (Agardh) LangeBertalot and Synedra ulna (Nitzsch) Ehrenberg. These species, except $R$. abbreviata, were negatively associated with CCA axis 2 .

\section{Discussion}

As pollution increased, low pollution tolerant species such as E. bilunaris, A. ambigua, A. granulata and $C$. naviculiformis were replaced by high pollution tolerant species such as G. parvulum, N. palea, N. praecipua, $R$. abbreviata and $S$. pupula. The latter group of species has been reported to be associated with waters of relatively high ionic strength and high conductivity, and is known to be resistant to organic and heavy metal pollution (Biggs and Kilroy, 2000; Potapova and Charles, 2003; Duong et al., 2006) that accompanied the downstream gradient in this study. These species have also been frequently recorded in waters that are nutrient rich and poorly oxygenated (Round, 1991).

Working on epipelic diatoms in the streams of Argentina in a similar environment as in this study, Licursi and Gómez (2001) associated R. abbreviata with levels 0 to 2 of their Pampean Diatom Index (IDP) i.e. unpolluted to moderately polluted respectively. This species has also been frequently reported in rivers in Japan where it is classified as sensitive to pollution (Kobayasi and Mayama, 1989; Asai and Watanabe, 1995). Studies in the streams of Yamuna, Delhi, confirmed $N$. palea to be tolerant of organic pollution due to sewage effluent (Dakshine and Soni, 1982). G. parvulum has also been shown to be tolerant of organic pollution (Kelly and Whitton, 1995; Lobo et al., 2004a) which was also typical of the study area.

Recent studies of environmental monitoring, using diatom communities in hydrological systems in GuaíbaRS, have demonstrated the importance of eutrophication in structuring benthic diatom communities (Lobo et al., 1999; Lobo et al., 2002, 2003, 2004a, b, c, d, e; Oliveira et al., 
2001; Rodrigues and Lobo, 2000; Wetzel et al., 2002; Hermany et al., 2006; Salomoni et al., 2006; Dupont et al., 2007). In this study TN and TP (and consequently the level of eutrophication) were found to be significantly different ( $\mathrm{p} \leq 0.05$ ) between the polluted and unpolluted sites that were characterised by different diatom community structures. Eutrophication is therefore an important factor in determining the structure of benthic diatom communities in the study area.

Lange-Bertalot (1979) stated that species are indicative of the upper limits of pollution that they can tolerate, and not the lower limit. Thus species which develop well in polluted (eutrophic) zones (e.g. G. parvulum, N. palea, $N$. praecipua, $R$. abbreviate and $S$. pupula in this case) may also occur in fairly clean water. Their value as indicators is their presence in polluted water.

Based on cluster analysis results, site 7 , which was the furthest downstream, tended to be more similar to the upstream relatively less polluted sites compared to the other sites in terms of community structure and water quality. This could be due to the process of stream self-purification, which is a collective expression for a large number of biogeochemical and hydrological processes that temporarily decrease, decay, degrade, transform, or permanently retard and remove pollutants from the river channel (Spellman, 1996). This self-purification process is very effective and the system will suffer no permanent damage as long as its capacity has not been exceeded (Bere, 2007). If this capacity is exceeded the system will become ecologically stressed with the symptoms of pollution becoming increasingly obvious and extensive as on site 6 .

From the forward stepwise multiple regression and CCA results, altitude was found to be important in determining the diversity of epipsammic diatoms in the study area. This is well in agreement with other works emphasising the importance of altitude in structuring benthic diatom communities in lotic systems (e.g. Ter Braak and van Dam, 1989; Round, 1991; Biggs, 1990, 1995; Patrick and Hendrickson, 1993; Biggs and Kilroy, 2000; Potapova and Charles, 2003, 2005; Duong, 2007).

Benthic diatom communities (and unicellular organisms in general) are traditionally considered to be more regulated by local environmental conditions than by broad-scale climatic, vegetational and geological factors (Pan et al., 1996; Leland et al., 2001, Moura et al., 2007). However, this view has been recently challenged by Kociolek and Spaulding (2000) and Mamm and Droop (1996) who ague that a considerable proportion of diatoms are in fact endemic or at least show a regionally restricted distribution. According to their view therefore, in explaining the distribution of benthic diatoms, more emphasis should be given to broadscale climatic, vegetational and geological factors.

The results of this study support the view that diatom communities exhibit a strong spatial component, with distinctly different communities in different parts of the study area. Although many taxa in this study were truly cosmopolitan, some species exhibited restricted distributions, with altitude and pollution levels playing a major role in governing the distribution patterns. For example, C. naviculiformis and A. granulata were generally found in high altitude relatively clean sites while $G$. parvulum and $N$. palea were found in low altitude polluted sites.

Canopy cover (which was highly negatively correlated to temperature, light intensity and mean stream width) and turbidity were also found to be important in structuring benthic diatom communities in the study area as they were retained after forward stepwise multiple regression. This is because of the importance of light for diatom photosynthesis (Round, 1991; Pan et al., 1996; Potapova and Charles, 2002).

Biological monitoring of lotic systems using benthic diatoms, a tool that has proved to be important worldwide (e.g. Schoeman, 1979; Gasse et al., 1995; Lowe and Pen, 1996; John, 1998; Kelly et al., 1998; Prygiel et al., 1999; Loez and Topalian, 1999; Chessman et al., 1999; Rothfritz et al., 1997; Lobo and Callegaro, 2000; Fernandes and Esteves, 2003, Lobo et al., 2004a,b,c,d,e; Lobo et al., 2006), has received less attention in the study area. A lot of studies carried out in southern Brazil confirmed diatoms as excellent indicators of environmental conditions (especially eutrophication) in lotic system (e.g. Lobo and Torgan, 1988; Rosa et al., 1988; Lobo et al., 1991, 1995b, 1996; Lobo and Callegaro, 2000, Lobo et al., 2004a,b,c,d,e; Burliga et al., 2005; Lobo et al., 2006; Hermany et al., 2006; Schneck et al., 2007; Salomoni et al., 2008). However, the studies are concentrated or restricted mainly to the southern part of the country (Tundisi, 2006), and very little has been done in other lotic systems. In Central America, Michels-Estrada (2003) investigating the ecology of benthic diatom communities in several rivers and streams of Costa Rica, highlights the urgent need to establish a base of information on the ecology of aquatic ecosystems in the tropics in order to develop efficient methodologies for monitoring water quality. This is also supported by the work of Silva-Benavides (1996a, b).

We propose that diatom indices from elsewhere, especially in the southern part of Brazil where more studies have been carried out and the first Brazilian-base index of water quality monitoring using diatoms, Biological Index of Water Quality (BIWQ), was developed initially by Lobo et al., (2002) and completed by Lobo et al., (2004a), be used for gaining support and recognition for diatom-based approaches to water quality monitoring and for allowing sample and data collection which can then be used later in the formulation of diatom indices unique to the study area.

Acknowledgements — This study was made possible by the provision of funds from the Third World Academy of Science (TWAS) through the Conselho Nacional de Desenvolvimento Científico e Tecnológico (CNPq). We also wish to thank the Insttituto Internacional de Ecologia management and staff for their support during the course of this study. 


\section{References}

ALLAN, JD. and FLECKER, AF. 2003. Biodiversity conservation in running waters: identifying the major factors that threaten destruction of riverine species and ecosystems. Biological Sciences, vol. 43 , no. 1 , p. $32-43$.

ASAI, K. and WATANABE, T. 1995. Statistic classification of epilithic species into three ecological groups relating to organic water pollution (2) Saprophilous and Saproxenous taxa. Diatom, vol. 10 , no. 1 , p. $35-47$.

BERE, T. 2007. The assessment of nutrient loading and retention in the upper segment of the Chinyika River, Harare: implications for eutrophication control. Water SA, vol. 33, no. 2, p. 279-284

BICUDO, CEM. and MENEZES, M. 2006. Gêneros de água de águas continentais do Brazil: chave para identificação e descrições. São Carlos: Rima. p. 391-439.

BIGGS, BJF. and KILROY, C. 2000. Stream priphyton monitoring manual. New Zealand: NIWA.

BIGGS, BJF. 1990. Periphyton communities and their environmental gradients in New Zealand rivers. New Zealand Journal of Freshwater Research, vol. 24, no. 3, p. 367-386.

BIGGS, BJF. 1995. The contribution of flood disturbances, catchment geology and land use to the habitat template of periphyton in stream ecosystems. Freshwater Biology, vol. 33, no. 3 , p. 419-438.

BOURRELLY, P. 1981. Les algues d'eau douce: initiation à la systematique. Paris: Société Nouvelle des Editions Boubée. p. 243-399.

CHESSMAN, B., GROWNS, I., CURREY, J. and PLUNKETTCOLE, N. 1999. Predicting diatom communities at the genus level for the rapid biological assessment of rivers. Freshwater Biology, vol. 41 , no. 2 , p. $317-331$.

DAMITROVIC, YZ., NEIFF, ASGP. and CASCO, SL. 2007. Abundante and diversity of phytoplankton in the Paraná River (Argentina) $220 \mathrm{~km}$ downstream of the Yacyretá reservoir. Brazilian Journal of Biology, vol. 67, no. 1, p. 53-63.

DASKSHINE, KMM. and SONI, JK. 1982. Diatom distribution and status of organic pollution in sewage drains. Hydroniologia, vol. 87 , no. 3, p. 205-209.

DELGADO, SM. and SOUZA, MGM. 2007. Diatomoflórula do rio Descoberto-DF e GO, Brazil, Naviculales (Bacillariophyceae): Diploneidineaes e Sellaphorineae. Acta Botanica Brasilica, vol. 21, no. 4, p. 767-776.

DOUNG, TT., FEURTET-MAZAL, A., COSTE, M., DANG, DK. and BOUDOU, A. 2007. Dynamics of diatom colonization processes in some rivers influenced by urban pollution (Hanoi, Vietnam). Ecological Indicators, vol. 7, no. 4, p. 839-851.

DUONG, TT., COSTE, M., FEURTET-MAZEL, A., DANG, D., GOLD, C., PARK, Y. and BOUDOU, A. 2006. Impact of Urban Pollution from the Hanoi Area on Benthic Diatom Communities Collected from the Red, Nhue and Tolich Rivers (Vietnam). Hydrobiologia, vol. 563, no. 3, p. 201-216.

FERNANDES, VO. and ESTEVES, FA. 2003. The use of indices for evaluating the periphytic community in two kinds of substrate in Imboassica lagoon, Rio de Janeiro, Brazil. Brazilian Journal of Biology, vol. 63, no. 2, p. 233-243.
GASSE, F., JUGGINS, S. and KHELIFA, LB. 1995. Diatom-based transfer functions for inferring past hydrochemical characteristics of African lakes. Palaeogeography and Palaeoecology, vol. 117, no. 1-2, p. 31-54.

GOLTERMAN, HL., CLYMO, RS. and OHNSTAD, MAM. 1978. Methods for physical and chemical analysis of fresh waters. Oxford: Blackwell Scientific Publication. p. 213. (IBP Handbook, 8)

GOMEZ, N. and LICURSI, M. 2001. The Pampean Diatom Index (IDP) for assessment of rivers and streams in Argentina. Aquatic Ecology, vol. 35, no. 9, p. 173-181.

HAMMER, O., HARPER, DAT., RYAN, PD. 2009. PAST: Palaeontological Statistics. Version 1.90. Norway: Palaeontological Association. Available from: <http://folk.uio.no/ohammer/past>. Access in: 19/01/2008.

HERMANY, G., LOBO, EA., SCHWARZBOLD, A. and OLIVEIRA, MA. 2006. Ecology of the epilithic diatom community in a loworder stream system of the Guaíba hidrographical region: subsidies to the environmental monitoring of southern Brazilian aquatic systems. Acta Limnologica Brasiliensia, vol. 18, no. 1, p. 9-27.

JOHN, J. 1998. Diatoms: tools for bioassessment of river health. A model for South-Western Australia. Canberra: Land \& Water Australia. $388 \mathrm{p}$.

JOHN, J. 2000. Diatom prediction and classification system for urban streams. Canberra: LWRRDC.

KARR, JR. 1991. Biological integrity: a long-neglected aspect of water resource management. Ecological Applications, vol. 1, no. 1 , p. $66-84$.

KELLY, MG. and WHITTON, BA. 1995. The trophic diatom index: a new index for monitoring eutrophication in rivers. Journal of Applied Phycology. vol. 7, no. 4, p. 433-444.

KELLY, MG., CAZAUBON, A., CORING, E., DELL'UOMO, A., ECTOR, L., GOLDSMITH, B., GUASCH, H., HÜRLIMANN, J., JARLMAN, A., KAWECKA, B., KWADRANS, J., LAUGASTE, R., LINDSTROM, EA., LEITAO, M., MARVAN, P., PADISÁK, J., PIPP, E., PRYGIEL, J., ROTT, E., SABATER, S., VAN DAM, H. and VIZINET, J. 1998. Recommendations for the routine sampling of diatoms for water quality assessments in Europe. Journal of Applied Phycology, vol. 10, no. 2, p. 215-224.

KOBAYASI, H. and MAYAMA, S. 1989. Evaluation of river water quality by diatoms. The Korean Journal of Phicology, vol. 4, no. 2, p. 121-133.

KOCIOLEK, JP. and SPAULDING, AA. 2000. Freshwater diatom biogeography. Nova Hedwigia Beihelf, vol. 71, no. 1-2, p. 223-241

KRECJI, ME. and LOWE, RL. 1986. Importance of sand grain mineralogy and topography in determining micro-spatial distribution of episommic diatoms. Journal of north American Bethological Society, vol. 5, no. 1, p. 211-220.

LANGE-BERTALOT, H. 1979. Pollution tolerance of diatoms as criteria for water quality estimation. Nova Hedwigia, vol. 64, no. 1, p. 283-304.

LELAND, HV., BROWN, LR. and MUELLER, DK. 2001. Distribution of algae in San Joaquin River, California, in relation to nutrient supply, salinity and other environmental factors. Freshwater Biology, vol. 46, no. 9, p. 1139-1167. 
LOBO, EA. and KOBAYASI, H. 1990. Shannon's diversity index applied to some freshwater diatom assemblages in the Sakawa River system (Kanagawa Pref., Japan) and its use as an indicator of water quality. Japanese Journal of Phycology, vol. 38, no. 2, p. 229-243.

LOBO, EA. and TORGAN, LC. 1988. Análise da estrutura da comunidade de diatomáceas (Bacillariophyceae) em duas estações do sistema Guaíba, RS, Brasil. Acta Botânica Brasílica, vol. 1, no. 2, p. 103-119.

LOBO, EA., OLIVEIRA, MA., NEVES, MT. and SCHULER, S. 1991. Caracterização de ambientes de terras úmidas, no Estado do Rio Grande do Sul, onde ocorrem espécies de anatídeos com valor cinegético. Acta Biológica Leopoldensia, vol. 13, no. 1, p. $19-60$.

LOBO, EA., KATOH, K. and ARUGA, Y. 1995a. Response of epilithic diatom assemblages to water pollution in rivers in the Tokyo metropolitan area, Japan. Freshwater Biology, vol. 34, no. 1, p. 191-204.

LOBO, EA. 1995b. Avaliação da qualidade das águas doces continentais utilizando diatomáceas: uma proposta para o intercâmbio tecnológico e científico entre Brasil e Japão. In Anais do Concurso Nacional de Monografias. São Paulo: USP.

LOBO, EA., CALLEGARO, VLM., OLIVEIRA, MA., SALOMONI, SE., SCHULER, S. and ASAI, K. 1996. Pollution tolerant diatoms from lotic systems in the Jacui Basin, Rio Grande do Sul, Brasil. Iheringia, Série Botânica, vol. 47, no. 1, p. 45-72.

LOWE, RL. and PAN, Y. 1996. Benthic algal communities as biological indicators. In STEVENSON, RJ., BOTHWELL, ML. and LOWE, RL. (Eds.). Algal ecology: freshwater benthic ecosystems. San Diego: Academic Press. p. 705-739.

LOBO, EA., CALLEGARO, VLM., BENDER, EP. and ASAI, K. 1998. Water quality assessment of rivers of Southern Brazil using epilithic diatom assemblages. In Proceedings of the 15 International Diatom Symposium. Australia: Editora.

LOBO, EA., BEM, DA., COSTA, A. and KIRST, A. 1999. Avaliação da qualidade da água dos arroios Sampaio, Bonito e Grande, Município de Mato Leitão, RS, Brasil, segundo a resolução do CONAMA 20/86. Revista Redes, vol. 4, p. 129-146.

LOBO, EA. and CALLEGARO, VL. 2000. Avaliação da qualidade de águas doces continentais com base em algas diatomáceas epilíticas: enfoque metodológico. In TUCCI,CEM. and MARQUES, DM. (Eds.). Avaliação e controle da drenagem urbana. Porto Alegre: UFRGS. p. 277-300.

LOBO, EA., CALLEGARO, VL. and BENDER, P. 2002. Utilização de algas diatomáceas epilíticas como indicadoras da qualidade da água em rios e arroios da Região Hidrográfica do Guaíba, RS, Brasil. Santa Cruz do Sul: EDUNISC. 126 p.

LOBO, EA., WETZEL, CE. and BES, D. 2003. Avaliação da qualidade da água dos arroios Sampaio, Bonito e Grande, Municípío de Mato Leitão, RS, Brasil. Revista Tecnológica, vol. 7, no. 1, p. 39-53.

LOBO, EA., CALLEGARO, VL., HERMANY, G., BES, D., WETZEL, CE. and OLIVEIRA, MA. 2004a. Use of epilithic diatoms as bioindicator from lotic systems in southern Brazil, with special emphasis on eutrophication. Acta Limnologica Brasiliensia, vol. 16 , no. 1 , p. $25-40$.

LOBO, EA., CALLEGARO, VL., HERMANY, GN. and ECTOR, L. 2004b. Review of the use of microalgae in South America for monitoring rivers, with special reference to diatoms. Vie et Milieu, vol. 53 , no. 1 , p. $35-45$.
LOBO, EA., BES, D., TUDESQUE, L. and ECTOR, L. 2004c. Water quality assessment of the Pardinho River, RS, Brazil, using epilithic diatom assemblages and faecal coliforms as biological indicators. Vie et Milieu, vol. 53, no. 2-3, p. 46-53.

LOBO, EA., CALLEGARO, VL., WETZEL, CE., HERMANY, G. and BES, D. 2004d. Water quality study of Condor and Capivara streams, Porto Alegre municipal district, RS, Brazil, using epilithic diatoms biocenoses as bioindicators. Oceanological and Hydrobiological Studies, vol. 33, no. 1, p. 77-93.

LOBO, EA., CALLEGARO, VLM., HERMANY, G., BES, D., WETZEL, C. and OLIVEIRA, MA. 2004e. Utilização de algas diatomáceas como indicadores de eutrofização em sistemas aquáticos sul brasileiros. In Anais do Workshop Bioindicadores de Qualidade da Água. São Paulo: EMBRAPA. (CD-ROM).

LOBO, EA., SALOMONI, S., ROCHA, O. and CALLEGARO, VL. 2006. Epilithic diatoms as indicatores of water quality in the Gravataí river, Rio Grande do Sul, Brazil. Hydrobiologia, vol. 559, no. 1-2, p. 233-246.

MANN, DG. 1999. The species concept in diatoms. Phycology, vol. 38 , no. 3, p. 437-495.

MICHELS-ESTRADA, A. 2003. Ökologie und Verbreitung von Kiesenalgen in Fließgewässern Costa Rica als Grundlage für eine biologische Gewässergüteberteilung in den Tropen. Dissertationes Botanicae, vol. 377, no. 1-2, p. 244.

MIZUNO, T. 1964. Illustrations of freshwater plankton of Japan. Osaka: Hoikusha Publishing. p. 125-181.

MOURA, AN., BITTENCOURT-OLIVEIRA, MC. and NASCIMENTO, EC. 2007. Benthic Bacillariophyta of the Paripe River estuary in Pernambuco state, Brazil. Brazilian Journal of Biology, vol. 67, no. 3, p. 393-401.

NECCHI Jr., O., BRANCO, LHZ. and BRANCO, CCZ. 2003. Ecological distribution of stream macroalgal communities from a drainage basin in the Serra da Canastra National Park, Minas Gerais, south-eastern Brazil. Brazilian Journal of Biology, vol. 63, no. 1 , p. 635-646.

OLIVEIRA, MA., TORGAN, LC., LOBO, EA. and SCHARZBOLD, A. 2001. Association of periphytic diatom species of artificial substrate in lotic environments in the Arroio Sampaio basin, RS, Brazil: relationships with abiotic variables. Brazilian Journal of Biology, vol. 6, no. 4, p. 523-540.

PAN, Y., STEVENSON, RJ., HILL, BH., HERLIHY, AT. and COLLINS, GB. 1996. Using diatoms as indicators of ecological conditions in lotic systems: a regional assessment. Journal of North American Bethological Society, vol. 15, no. 4, p. 481-495.

PATRICK, R. and HENDRICKSON, J. 1993. Factors to consider in interpreting diatom changes. Nova Hedwigia Beihelf, vol. 106, no. 2, p. 361-377.

PATRICK, R. and REIMER, CW. 1966. The diatoms of the United States. Philadelphia: Academy of Natural Sciences.

POTAPOVA, MG. and CHARLES, DF. 2002. Benthic diatoms in USA rivers: distributions along speciation and environmental gradients. Journal of Biogeography, vol. 29, no. 8, p. 167-187.

POTAPOVA, M. and CHARLES, DF. 2003. Distribution of benthic diatoms in US rivers in relation to conductivity and ionic composition. Freshwater Biology, vol. 48, no. 2, p. 1311-1328. 
POTAPOVA, M. and CHARLES, DF. 2005. Choice of substrate in algae-based water quality assessment. Journal of North American Benthological Society, vol. 24, no. 2, p. 415-427.

PRYGIEL, J., WHITTON, BA. and BUKOWSKA, J. 1999. Use of algae for monitoring rivers III. Douai: Agence de L'Eau Artois-Picardie. p. 271.

ROCHA, AA. 1992. Algae as indicators of water pollution. In CORDEIRO-MARINO, M., AZEVEDO, MTP., SANT'ANNA, CL., TOMITA, NY. and PASTINO, EM. (Eds.). Algae and environment: a general approach. São Paulo: Sociedade Brasileira de Ficologia. p. 34-55.

ROSA, ZM., TORGAN, LC. and HERZOG, LAW. 1988. Análise da estrutura de comunidades fitoplanctônicas e de alguns fatores abióticos em trecho do Rio Jacuí, Rio Grande do Sul, Brasil. Acta Botanica Brasilica, vol. 2, no. 1, p. 31-46.

ROTHFRITZ, H., JUTTNER, I., SUREN, AM. and ORMEROD, SJ. 1997. Epiphytic and epilithic diatom communities along environmental gradients in the Nepalese Himalaya: implications for the assessment of biodiversity and water quality. Archive für Hydrobiologia, vol. 138, no. 3, p. 465-482.

ROUND, FE. 1991. Diatoms in river water-monitoring studies. Journal of Applied Phycolology, vol. 3, no. 1, p. 129-145.

SALOMONI, SE. and TORGAN, LC. 2008. Epilithic diatoms as organic contamination degree indicators in Guabia Lake, southern Brazil. Acta Limnologica Brasiliensia, vol. 20, no. 3, p. 313-324.

SALOMONI, SE., ROCHA, O., CALLEGARO, VL. and LOBO, EA. 2006. Eplithic diatoms as indicators of water quality in the Gravataí river, Rio Grande do Sul, Brazil. Hydrobiologia, vol. 559, no. 2, p. 233-246.

SCHNECK, F., TORGAN, LC. and SCHWARZBOLD, A. 2007. Epilithic diatom community in a high altitude stream impacted by fish farming in southern Brazil. Acta Limnolica Brasiliensia, vol. 19 , no. 4 , p. 341-355.

SCHOEMAN, FR. 1979. Diatoms as indicators of water quality in the upper Hennops River. Journal of Limnological Society of South Africa, vol. 5, p. 73-78.

SHANNON, CE. and WEAVER, W. 1949. The mathematical theory of communication. Urbana: University of Illinois Press.
SILVA-BENAVIDES, AM. 1996a. The use of water chemistry and benthic diatom communities for qualification of a polluted tropical river in Costa Rica. Revista de Biologia Tropical, vol. 44, no. 2, p. 395-416.

SILVA-BENAVIDES, AM. 1996b. The epilithic diatom flora of a pristine and a polluted river in Costa Rica, Central America. Diatom Research, vol. 11, no. 1, p. 105-142.

SOARES, MCS., SOPHIA, MG. and HUSZAR, VLM. 2007. Phytoplankton flora of two rivers in Southern Brazil-Paraibuna and Pomba Rivers, Minas Gerais. Revista Brasileira de Botânica, vol. 30 , no. 4 , p. $433-450$.

SONNEMAN, JA., WALSH, CJ., BREEN, PF. and SHARPE, AK. 2001. Effects of urbanization on streams of the Melbourne region, Victoria, Australia. II. Benthic diatom communities. Freshwater Biology, vol. 46, no. 4, p. 553-560.

SPELLMAN, FR. 1996. Stream ecology and self-purification: an introduction for wastewater and water specialists. Pennyevania: Technomic Publishing Company.

STEVENSON, RJ. 1997. Scale-dependent determinants and consequences of benthic algal heterogeneity. Journal of North American Bethological Society, vol. 16, no. 1, p. 248-263.

TER-BRAAK, CJF. and Van DAM, H. 1989. Inferring $\mathrm{pH}$ from diatoms: a comparison of old and new methods. Hydrobiologia, vol. 178, no. 1, p. 209-223.

TER-BRAAK, CJF. 1988. The theory of gradient analysis. Advance Ecological Research, vol. 18, no. 1, p. 271-313.

TUNDISI, JG. and MATSUMURA-TUNDISI, T. 2008. Limnologia. São Paulo: Câmara Brasileira do Livro.

TUNDISI, JG. 2006. O futuro dos recursos hídricos no Brasil. Safari Air Emp. Ltda, Brazilia: Safari Air Emp. Ltda,:PROJETO Brasil das Águas. Available from: <http://www.brasildasaguas. com.br/>. Access in: 19/01/2010.

VALDERRAMA, JC. 1981. The simultaneous analysis of total nitrogen and total phosphorus in natural water. Marine Chemistry, vol. 10 , no. 2 , p. 102-122

ZAR, JH. 1984. Biostatistical analysis. New Jersey: Prentice Hall. 